\title{
PENINGKATAN MOTIVASI BELAJAR IPA MELALUI \\ METODE PEMBELAJARAN QUANTUM TEACHING BAGI SISWA KELAS IV
}

\author{
Fauzatul Ma'rufah Rohmanurmeta \\ Pendidikan Guru Sekolah Dasar FIP IKIP PGRI Madiun \\ ayuputri368@yahoo.com
}

\begin{abstract}
At the elementary school level, sains learning still monotonous and uninteresting because elementary school system with classroom teachers to make the teachers have difficulty in using the right strategy. Teachers are required to achieve the target material that is quite a lot and should be comleted in each semester.This situation resulted in the lack of attention of student in the process of learning activities so that a low student motivation. Under these conditions, the purpose of this research is to improve students motivation through quantum teaching method of learning process in the fourth grade students of SDN 02 Wates Distric jenangan, Ponorogo.This research is a classroom action research (PTK), which consists of the first cycle and the second cycle. The study subjects were students of class 4 SDN 02 Wates wich consist 11 students. Collecting data in this study using a questionnaire to determine students motivation, and the observation sheet in the form of check list to determine the activity of students. Before held research student motivation is low. Then after research showed that motivation of students of cycle $145,5 \%$ and cycle II 82\% increased 36,5\%. Interpretation of student learning to learning in sycle 1 is $36 \%$ and cycle II increased to $82 \%$. Student activity in I cycle was $27,3 \%$ and in the II cycle increased to $81,8 \%$. The result showed that the use of quantum teaching methods can improve students motivation in learning sains SDN 02 wates.
\end{abstract}

Keywords: motivation in learning, sains, quantum teaching methods

\begin{abstract}
Abstrak
Di tingkat sekolah dasar, pembelajaran IPA masih monoton dan tidak menarik karena keadaan SD dengan sistem guru kelas membuat guru mengalami kesulitan dalam menggunakan strategi yang tepat. Guru dituntut untuk mengejar target materi yang cukup banyak dan harus diselesaikan pada tiap semester. Keadaan ini mengakibatkan kurangnya perhatian siswa dalam proses kegiatan pembelajaran sehingga motivasi belajar siswa rendah. Berdasarkan hal tersebut maka tujuan penelitian ini adalah untuk meningkatkan motivasi belajar siswa melalui metode quantum teaching dalam proses pembelajaran IPA pada siswa kelas IV SDN 2 Wates, Kec. Jenangan, Kab. Ponorogo. Penelitian ini merupakan penelitian tindakan kelas (PTK) yang terdiri dari siklus I dan siklus II. Subyek penelitian ini adalah siswa kelas IV SDN 2 Wates yang berjumlah 11 siswa. Pengumpulan data dalam penelitian ini dengan menggunakan angket untuk
\end{abstract}


mengetahui motivasi belajar siswa, tes untuk mengetahui prestasi belajar siswa, dan lembar observasi berupa ckek list untuk mengetahui aktivitas siswa. Sebelum diadakan penelitian, motivasi belajar siswa masih rendah. Kemudian setelah dilakukan penelitian diketahui bahwa motivasi siswa dari siklus I 45,5\% dan pada siklus II $82 \%$ mengalami peningkatan $36,5 \%$. Prestasi belajar siswa terhadap pembelajaran pada siklus I adalah $36 \%$ dan pada siklus II meningkat menjadi $82 \%$. Aktivitas siswa pada siklus I adalah $27,3 \%$ dan pada siklus II meningkat menjadi $81,8 \%$. Hasil penelitian menunjukkan bahwa penggunaan metode quantum teaching dapat meningkatkan motivasi belajar siswa dalam pembelajaran IPA kelas IV SDN 2 Wates.

Kata Kunci: Motivasi Belajar, IPA, Metode Pembelajaran Quantum Teaching

\section{A. Pendahuluan}

Keberhasilan pengajaran

IPA tergantung pada keberhasilan siswa dalam proses belajar, sedangkan keberhasilan siswa tidak hanya tergantung pada sarana dan prasarana pendidikan, kurikulum maupun metode. Akan tetapi guru mempunyai posisi yang sangat strategis dalam meningkatkan prestasi siswa dalam penggunaan strategi pembelajaran yang tepat.

Berdasarkan pengamatan proses pembelajaran IPA di kelas IV SDN 2 Wates, Kecamatan Jenangan, Kabupaten Ponorogo ditemukan bahwa kegiatan pembelajaran disekolah monoton dan tidak menarik karena keadaan SD dengan sistem guru kelas membuat guru mengalami kesulitan dalam menggunakan strategi pembelajaran yang tepat, sedangkan guru dituntut untuk mengejar target materi yang cukup banyak dan harus diselesaikan pada tiap semester. Keadaan ini mengakibatkan kurangnya perhatian siswa dalam proses kegiatan pembelajaran sehingga motivasi belajar siswa rendah. Dari situasi dan kondisi seperti ini mempengaruhi proses belajar mengajar yang sedang berlangsung. Berdasarkan hasil pengamatan tersebut diatas dapat dikatakan bahwa proses pembelajaran di SDN 2 Wates kurang optimal sehingga menyebabkan penurunan mata pelajaran IPA. Hal ini terlihat dari minat dan pengetahuan siswa masih rendah. Demikian juga hasil ulangan setelah dianalisis baik secara individual maupun kelompok belum mendapatkan hasil yang optimal. Bahkann untuk mencapai criteria ketuntasan minimal, hanya mencapai $34 \%$ dari siswa yang mendapat nilai 65 keatas.

Salah satu metode pembelajaran yang memungkinkan siswa belajar secara optimal adalah metode pembelajaran quantum teaching. Menurut DePorter (2010:32) metode pembelajaran quantum teaching adalah perubahan pembelajaran yang meriah, dengan segala nuansanya dan 
menciptakan lingkungan belajar yang efektif. Interaksi-interaksi ini mencakup unsur-unsur untuk belajar efektif yang mempengaruhi kesuksesan siswa. Pembelajaran yang menyingkirkan hambatan yang menghalangi proses kegiatan belajar dengan cara sengaja menggunakan musik/mewarnai lingkungan sekeliling, menyusun bahan pengajaran yang sesuai pengajaran yang efektif dan banyak mengaktifkan siswa. Metode pembelajaran ini merupakan model percepatan belajar (accelerated learning) dengan metode belajar quantum teaching. Percepatan belajar yang di Indonesia dikenal dengan program akselerasi tersebut dilakukan dengan menyingkirkan hambatan-hambatan yang menghalangi proses alamiah dari belajar melalui upaya-upaya yang sengaja. Penyingkiran hambatanhambatan belajar yang berarti mengefektifkan dan mempercepat proses belajar dapat dilakukan, misalnya melalui penggunaan music (untuk menghilangkan kejenuhan sekaligus memperkuat konsentrasi melalui kondisi alfa), perlengkapan visual (untuk membantu siswa yang kuat kemampuan visualnya), materimateri yang sesuai dan penyajiannya disesuaikan dengan cara kerja otak, dan keterlibatan aktif (secara intelektual, mental dan emosional). Metode pembelajaran ini menekankan kegiatannya pada pengembangan potensi manusia secara optimal melalui caracara yang sangat manusiawi, yaitu: mudah, menyenangkan, dan memberdayakan.

Konsep quantum teaching memiliki azas utama yang terkenal dengan istilah, "bawalah dunia mereka ke dunia kita dan antarkan dunia kita ke dunia mereka".Maksudnya, pentingnya memasuki dunia peserta didik sebagai langkah untuk mendapatkan hak mengajar dari peserta didik dengan membangun jembatan autentik untuk memasuki kehidupan peserta didik. Azas utama quantum teaching menurut Bobbi DePorter (2005:35) adalah semua aspek kepribadian manusia. Semua aspek itu meliputi pikiran, perasaan, bahasa isyarat, pengetahuan, sikap dan keyakinan serta persepsi masa mendatang. Jadi belajar akan berhasil apabila dengan cara mengaitkan yang diajarkan dengan satu peristiwa, pikiran atau perasaan yang diperoleh dari kehidupan rumah.

Penyajian dalam pembelajaran quantum teaching merupakan metode pembelajaran yang ideal, karena menekankan kerjasama antara siswa dan guru untuk mencapai tujuan bersama. Metode pembelajaran ini juga efektif karena dapat meningkatkan motivasi belajar siswa sehingga memungkinkan siswa belajar secara optimal, yang pada gilirannya akan dapat meningkatkan prestasi belajar siswa secara signifikan. Oleh karena itu metode ini perlu dilaksanakan di sekolah-sekolah. Tujuan 
yang ingin dicapai dalam ini adalah pada bulan Desember 2012 penelitian ini adalah untuk sampai dengan bulan Mei 2013. Subyek mengetahui peningkatan motivasi belajar siswa melalui pembelajaran quantum teaching bagi siswa SDN 02 Wates.

\section{B. Metode Penelitian}

Penelitian dilaksanakan di SDN 2 Wates Kecamatan Jenangan, Kabupaten Ponorogo. Waktu untuk melakukan penelitian penelitian adalah siswa kelas IV SDN 2 Wates yang berjumlah 11 siswa dengan 6 siswa laki-laki dan 5 siswa perempuan. Penelitian ini merupakan penelitian tindakan kelas (PTK) yang meliputi 4 tahap pada setiap siklus yaitu: 1) perencanaan, 2) tindakan, 3) pengamatan, 4) refleksi. Desain Penelitian Tindakan Kelas dapat dilihat pada gambar berikut:

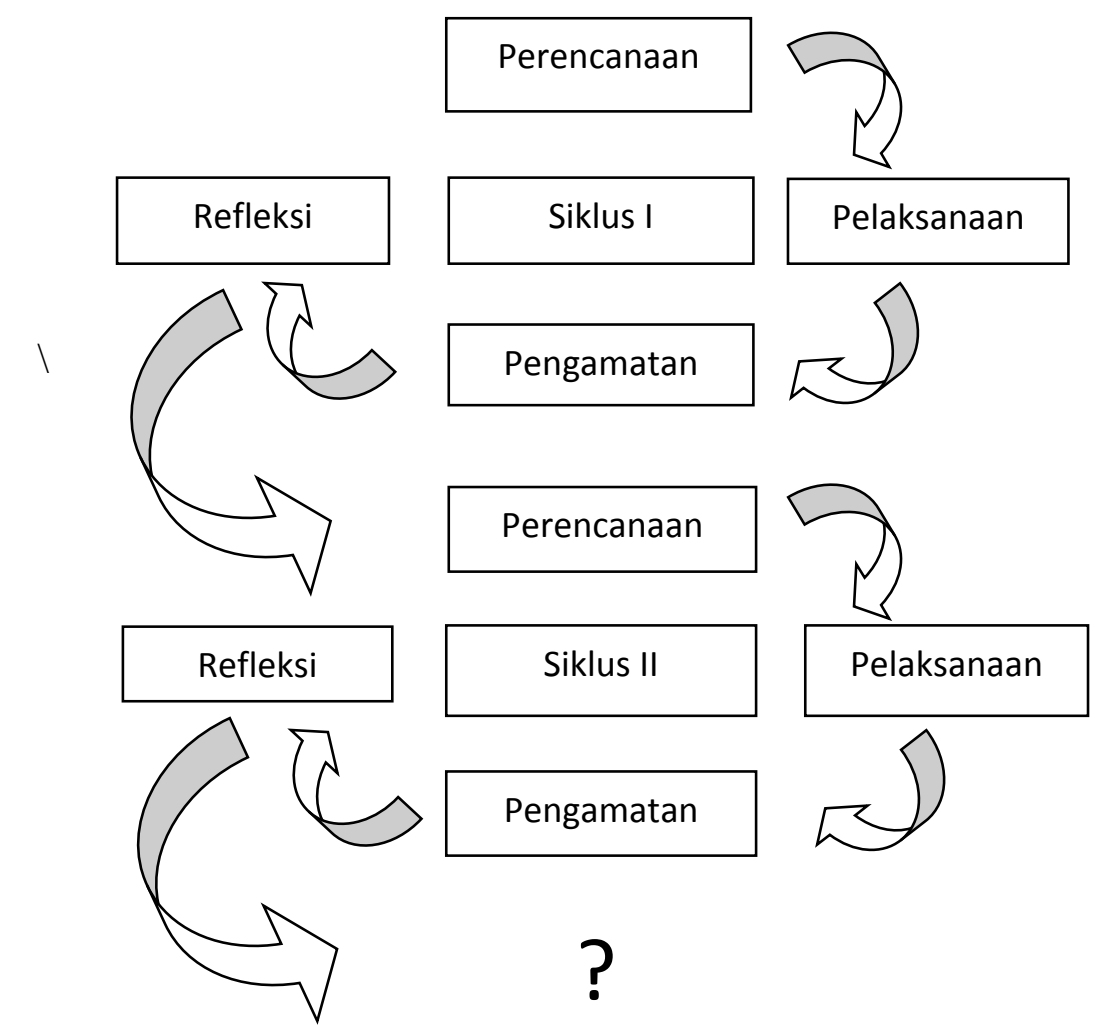

Gambar 1. Siklus Penelitian Tindakan Kelas (Arikunto, 2006:16)

Prosedur penelitian yang diterapkan dalam penelitian ini diuraikan sebagai berikut.

\section{Siklus I}

1. Perencanaan
a. Guru
mempersiapkan materi yang akan diajarkan. b. Guru mempersiapkan materi yang akan dibahas mengenai materi penampakan bulan.

c. Guru mempersiapkan alat peraga berupa gambar pertukaran bentuk bulan ketika menempuh lintasan bulan mengelilingi bumi. 
d. Guru menugaskan kepada siswa untuk membawa buku tulis khusus untuk catatan IPA

e. Guru mempersiapkan lembar kerja untuk siswa

f. Guru menyiapkan rencana pembelajaran dan instrument penilaian.

2. Pelaksanaan

a. Siswa diajak untuk bernyanyi bersama dan menyelesaikan permainan untuk membangkitkan minat belajar siswa.

b. Siswa memperhatikan penjelasan guru tentang pengaruh grafitasi bulan terhadap bumi.

c. Dibimbing guru siswa mengamati gambar pertukaran bentuk bulan ketika menempuh lintasan bulan mengelilingi bumi.

d. Guru mengadakan tanya jawab tentang pengaruh gravitasi bulan terhadap bumi, bagi anak yang tidak bias menjawab pertanyaan diberi hukuman, siswa yang bias menjawab diberi pujian.

e. Guru member hukuman bagi siswa yang tidak bias menjawab dengan cara menyanyi atau menari.

3. Pengamatan

a. Guru mengamati aktifitas siswa dalam menerima pelajaran. b. Guru menyuruh semua siswa untuk mengerjakan lembar evaluasi.

c. Guru mengadakan penilaian terhadap hasil pekerjaan siswa.

4. Refleksi

Guru mengungkapkan hasil pengamatan terhadap siswa tentang kerjasama dalam kelompok. Hasil pengamatan dicari pemecahannya, sehingga dalam tidakan siklus II ada perbaikan. Dilakukan tindakan siklus II karena siklus I belum bias memenuhi target.

\section{Siklus II}

Pada siklus II dilakukan tahapantahapan seperti siklus I tetapi didahului dengan perencanaan ulang berdasarkan hasil-hasil yang diperoleh pada siklus I, sehingga kelemahan-kelemahan yang terjadi pada siklus I tidak terjadi pada siklus II. Beberapa indikator keberhasilan pada siklus II diharapkan dapat lebih baik disbanding siklus I.

Sumber data dalam penelitian diambil dari siswa selama proses pembelajaran berlangsung dengan menggunakan metode pembelajaran quantum teaching. Pengumpulan data diperoleh dari hasil belajar siswa yang terdiri dari data efektif, data kognitif, dan data aktifitas siswa selama kegiatan belajar mengajar berlangsung. Teknik pengumpulan data meliputi angket, tes dan observasi. Data afektif diambil dari motivasi belajar siswa yang diperoleh dengan menggunakan lembar angket dengan penilaian berbentuk skala likert. Data kognitif diperoleh dari belajar siswa, kemudian dianalisis dengan menggunakan rumus sebagai berikut: 
Nilai $=\frac{\sum \text { Skor } y \text { ang Didapat }}{\sum \text { Skor Maksimal }} \times 100$

Data aktifitas siswa diambil dari data keaktifan siswa dalam kegiatan pembelajaran yang diperoleh dengan menggunakan lembar observasi yang berbentuk check list.

\section{Hasil Penelitian}

Pada setiap siklus diadakan pengambilan data yang meliputi data motivasi belajar siswa, data prestasi belajar siswa, dan data aktivitas siswa. Hasil dari angket yang dibagikan pada siklus I sebagai berikut:

Tabel 1. Frekuensi Pencapaian Kriteria Motivasi Belajar Siswa Siklus I

\begin{tabular}{cccc}
\hline Nilai & $\begin{array}{c}\text { Freku } \\
\text { ensi }\end{array}$ & $\begin{array}{c}\text { Presen } \\
\text { tase }\end{array}$ & $\begin{array}{c}\text { Indi } \\
\text { kator }\end{array}$ \\
\hline $85-100$ & 3 & 27,3 & $\begin{array}{c}\text { Sangat } \\
\text { baik }\end{array}$ \\
\hline $70-80$ & 2 & 18,2 & Baik \\
\hline $55-69$ & 3 & 27,3 & Cukup \\
\hline $40-54$ & 1 & 9,0 & Kurang \\
\hline $0-39$ & 2 & 18,2 & $\begin{array}{c}\text { Sangat } \\
\text { kurang }\end{array}$ \\
\hline Jumlah & 11 & $100 \%$ & \\
\hline
\end{tabular}

Indikator ketercpaian motivasi

belajar siswa $\geq 70$ (baik)

Ketuntasan klasikalnya 75\%

Dari tabel siklus I diatas dapat diketahui frekuensi siswa yang mencapai kriteria baik dan sangat baik sebanyak 5 siswa atau 45,5\% dari seluruh siswa, hasil ini belum mencapai indikator yang ditentukan yaitu 75\%. Ketuntasan belajar siswa dapat diketahui dengan melakukan tes diakhir kegiatan pembelajaran. Hasil ketuntasan belajar pada siklus I dapat dilihat pada tabel 2 beriku:

Tabel 2. Pencapaian Ketuntasan Belajar siswa siklus I

\begin{tabular}{lccc}
\hline KKM & $\begin{array}{c}\text { Freku } \\
\text { ensi }\end{array}$ & $\begin{array}{c}\text { Presen } \\
\text { tase }\end{array}$ & $\begin{array}{c}\text { Keterang } \\
\text { an }\end{array}$ \\
\hline$\geq 65$ & 4 & 36 & Tuntas \\
\hline$<65$ & 7 & 64 & $\begin{array}{c}\text { Belum } \\
\text { tuntas }\end{array}$ \\
& & & \\
\hline Jumlah & 11 & $100 \%$ & \\
\hline $\begin{array}{l}\text { Indikator ketercapaian prestasi belajar } \geq \\
\text { 65 }\end{array}$ \\
Ketuntasan klasikalnya $75 \%$
\end{tabular}

Dari tabel diatas dapat diketahui bahwa siswa yang memperoleh nilai lebih dari atau sama dengan 65 sebanyak 4 siswa, berarti $36 \%$ dari seluruh jumlah siswa yaitu 11 siswa sudah mencapai Kriteria Ketuntasan Minimal (KKM). Secara klasikal prestasi belajar siswa pada siklus I belum mencapai indikator yang ditentukan yaitu 75\%. Sedangkan pada penilaian aktifitas siswa terdapat 7 aspek nilai yang meliputi antusias siswa belajar IPA, motifasi belajar siswa dengan menggunakan metode pembelajaran quantum teaching, minat dan daya tarik siswa dalam belajar dengan menggunakan metode quantum teaching. Kesesuaian metode pembelajaran quantum teaching dengan materi pembelajaran IPA, kemampuan berfikir siswa dengan menggunakan metode quantum teaching. Kerjasama antara siswa dan guru dalam proses pembelajaran dengan menggunakan metode quantum teaching, dan keefektifan siswa belajar IPA menggunakan metode pembelajaran quantum teaching.

Hasil observasi pada siklus I sebagai berikut: 
Tabel 3. Frekuensi Pencapaian Kriteria aktivitas Belajar Siswa Siklus I

\begin{tabular}{cccc}
\hline Nilai & $\begin{array}{c}\text { Freku Presen } \\
\text { ensi }\end{array}$ & Indi kator \\
\hline $85-100$ & 2 & 18,2 & Sangat baik \\
\hline $70-80$ & 1 & 9,1 & Baik \\
\hline $55-69$ & 4 & 36,3 & Cukup \\
\hline $40-54$ & 1 & 9,1 & Kurang \\
\hline $0-39$ & 3 & 27,3 & Sangat kurang \\
\hline Jumlah & 11 & $100 \%$ & \\
\hline Indikator ketercpaian motivasi \\
belajar siswa $\geq 70$ (aktif) \\
\multicolumn{4}{l}{ Ketuntasan klasikalnya $75 \%$} \\
\hline
\end{tabular}

Dari tabel diatas dapat diketahui frekuensi siswa yang mencapai kriteria aktif dan sangat aktif sebanyak 3 siswa atau 27,3\% dari seluruh siswa, hasil ini belum mencapai ketercapaian klasikal yaitu 75\%. Dari hasil diatas makan peneliti menyimpulkan siklus I dan merumuskan tindakan pada siklus II. Hasl yang dibagikan pada siklus II sebagai berikut:

Tabel 4. Frekuensi Pencapaian Kriteria Motivasi Belajar Siswa Siklus II

\begin{tabular}{cccc}
\hline Nilai & $\begin{array}{c}\text { Freku } \\
\text { ensi }\end{array}$ & $\begin{array}{c}\text { Presen } \\
\text { tase }\end{array}$ & Indi kator \\
\hline $85-100$ & 6 & 55 & $\begin{array}{c}\text { Sangat } \\
\text { baik }\end{array}$ \\
\hline $70-80$ & 3 & 27 & Baik \\
\hline $55-69$ & 2 & 18 & Cukup \\
\hline $40-54$ & - & - & Kurang \\
\hline $0-39$ & - & - & $\begin{array}{c}\text { Sangat } \\
\text { Kurang }\end{array}$ \\
\hline Jumlah & 11 & $100 \%$ \\
\hline $\begin{array}{l}\text { Indikator ketercpaian motivasi belajar } \\
\text { siswa } \geq 70 \text { (baik) } \\
\text { Ketuntasan klasikalnya 75\% }\end{array}$ \\
\hline
\end{tabular}

Dari tabel diatas diketahui bahwa frekuensi siswa mencapai indikator motivasi belajar baik dan sangat baik adalah 9 siswa atau $82 \%$ dari seluruh siswa. Hasil tersebut sudah memenuhi indikator pencapaian klasikal yaitu $82 \%$ dari jumlah seluruh siswa sudah mencapai indikator baik dan sangat baik. Sedangkan ketuntasan belajar siswa dapat diketahui dengan melakukan tes diakhir kegiatanpembelajaran. Hasil dari ketuntasan belajar pada siklus II dapat dilihat pada tabel berikut:

Tabel 5. Pencapaian Ketuntasan Belajar siswa siklus II

\begin{tabular}{cccc}
\hline KKM & $\begin{array}{c}\text { Freku } \\
\text { ensi }\end{array}$ & $\begin{array}{c}\text { Presen } \\
\text { tase }\end{array}$ & Keterang an \\
\hline$\geq 65$ & 9 & 82 & Tuntas \\
\hline$<65$ & 12 & 18 & Tidak tuntas \\
\hline Jumlah & 11 & $100 \%$ & \\
\hline \multicolumn{4}{l}{ Indikator ketercapaian prestasi belajar $\geq 65$} \\
\hline
\end{tabular}

Dari tabel diatas dapat diketahui bahwa siswa yang mencapai ketuntasan belajar sebanyak 9 siswa atau $82 \%$ dari seluruh siswa. Secara klasikal prestasi belajar siswa pada siklus II sudah mencapai indikator yang ditentukan yaitu $75 \%$. Sedangkan hasil observasi yang telah dilakukan pada siklus II sebagai berikut:

Tabel 6 Frekuensi Pencapaian Kriteria aktivitas Belajar Siswa Siklus II

\begin{tabular}{cccc}
\hline Nilai & $\begin{array}{c}\text { Freku } \\
\text { ensi }\end{array}$ & $\begin{array}{c}\text { Presen } \\
\text { tase }\end{array}$ & Indi kator \\
\hline $85-100$ & 2 & 45,4 & Sangat baik \\
\hline $70-80$ & 1 & 36,4 & Baik \\
\hline $55-69$ & 4 & 18,2 & Cukup \\
\hline $40-54$ & 1 & - & Kurang \\
\hline $0-39$ & 3 & - & Kurang sekali \\
\hline Jumlah & 11 & $100 \%$ & \\
\hline & Indikator ketercpaian motivasi belajar \\
siswa $>70$ \\
Ketuntasan klasikalnya $75 \%$
\end{tabular}


Dari tabel diatas dapat diketahui frekuensi siswa yang mencapai indikator baik dan sangat baik sebanyak 9 siswa atau $81,8 \%$ dari seluruh siswa. Hasil observasi aktivitas siswa pada siklus II telah mencapai indikator klasikal 75\% karena 81,8\% dari keseluruhan siswa telah mencapai indikator baik dan sangat baik.

Dari pengamatan yang dilakukan guru dan peneliti, pada siklus II terdapaat peningkatan motivasi belajar serta peningkatan motivasi belajar serta peningkatan aktivitas siswa dalam kegiatan pembelajaran. Karena adanya peningkatan dari siklus I ke siklus II dan sudah mencapai indikator yang telah ditentukan, maka siklus dalam pembelajaran dihentikan sampai siklus II.

\section{Pembahasan}

Berdasarkan

hasil

penelitian dapat diketahui adanya peningkatan motivasi belajar siswa, prestasi belajar siswa, dan aktivitas siswa. Motivasi belajar siswa secara klasikal meningkat dari siklus I, 45,5\% menjadi $82 \%$ pada siklus II. Peningkatan ini terlihat pada antusiasme siswa pada saat mengikuti pelajaran. Siswa dengan sungguh-sungguh memperhatikan materi yang disampaikan guru dan memberikan respon aktif ketika mengucapkan kata dari sebuah huruf pertama yang diambil. Peningkatan motivasi belajar siswa terjadi karena siswa sangat antusias ketika proses Tanya jawab, mereka dengan cepat menemukan jawaban dan saling berlomba dengan temannya untuk mengutarakan jawabannya. Mereka masing-masing ingin mendapatkan hadiah.

Motivasi merupakan dasar yang mendorong aktivitas belajar siswa. Hal tersebut sesuai dengan pendapat Sardiman (2012:75) yang menjelaskan bahwa motivasi sebagai keseluruhan daya penggerak dalam diri peserta didik yang menimbulkan kegiatan belajar, yang menjamin kelangsungan dari kegiatan belajar dan yang memberikan arah pada kegiatan belajar, sehingga tujuan yang dikehendaki oleh subjek belajar itu dapat tercapai. Seseorang melakukan aktivitas belajar karena ada yang mendorongnya. Motivasi sebagai dasar penggeraknya yang mendorong seseorang untuk belajar. Bila seseorang sudah termotivasi untuk belajar, maka dia akan melakukan aktivitas untuk belajar, maka dia akan melakukan aktifitas dalam rentangan waktu tertentu.

Data prestasi belajar siswa diperoleh dari tes tertulis yang berbentuk isian yang telah dikerjakan setelah proses pembelajaran berlangsung. Indikator yang diharapkan jika 75\% keseluruhan siswa mendapat nilai minimal $\geq 65$. Sebelum diadakan penelitian dengan menggunakan metode quantum teaching hanya mencapai $34 \%$ dari siswa yang mendapat nilai 65 keatas. Dari hasil penelitian yang dilakukan dengan menggunakan metode 
quantum teaching menunjukkan adanaya peningkatan prestasi belajar dari siklus I ke siklus II, yang telah tercapai criteria ketuntasan minimal, sehingga terdapat peningkatan jumlah siswa yang tuntas belajar $78 \%$.

Prestasi belajar siswa secara klasikal terlihat pada hasil evaluasi siswa yang tuntas belajar meningkat dari siklus I $36 \%$ menjadi $82 \%$ pada siklus II, karena dengan diterapkannya metode pembelajaran quantum teaching siswa dapat lebih memahami materi. Siswa tidak hanya menerima materi yang disampaikan guru, tetapi mereka juga mengingatnya kembali dengan temannya dalam suasana yang menyenangkan. Mereka dapat belajar sambil bermain. Dengan mengulang kembali materi yang telah dipelajari maka ingatan siswa terhadap materi lebih kuat.

Prestasi belajar siswa sangat dipengaruhi oleh peran dan strategi guru dalam pembelajaran. Hal ini sesuai dengan pendapat Tulus Tu'u (2004:81) prestasi pembelajaran dipengaruhi oleh peran dan strategi guru dalam pembelajaran. Pertama, strategi pendekatan pribadi terhadap siswa yang kurang menonjol dalam bidang-bidang tertentu. Kedua, strategi guru melibatkan siswa dalam pembelajaran secara penuh dengan suasana gembira dan menyenangkan. Ketiga, strategi guru membuat alat bantu dan menciptakan ruangan yang hidup.

Aktivitas belajar siswa secara klasikal meningkat 54,5\%. Peningkatan aktivitas ini dapat terlihat ketika proses Tanya jawab. Mereka lebih cepat menjawab pertanyaan dari guru. Dengan metode pembelajaran quantum teaching aktivitas siswa dapat meningkat secara klasikal dari siklus I 27,3\% menjadi $81,8 \%$ pada siklus II karena suasana belajar sangat menyenangkan. Siswa tidak hanya diam mendengarkan materi yang disampaikan guru,tetapi siswa dapat belajar sambil bermain.

Proses belajar mengajar yang menyenangkan dapat mempengaruhi prestasi belajar siswa. Hal ini sesuai dengan pendapat Baharuddin (2010:53) menjelaskan bahwa "dalam proses belajar, sikap siswa belajar dapat dipengaruhi oleh perasaan senang atau tidak senang. Pada performan guru, pelajaran, atau lingkungan sekitarnya. Untuk mengantisipasi munculnya sikap yang negative dalam belajar guru dapat melakukan beberapa, diantaranya berusaha mengembangkan kepribadian sebagai seorang guru yang empatik dan sabar menyajikan pelajaran yang diampunya dengan baik dan menarik sehingga dapat membuat siswa mengikuti pelajaran dengan senang dan tidak menjemukan. Berdasarkan penelitian diatas prestasi belajar siswa yang meningkat dan dalam proses pembelajaran mendukung motivasi belajar siswa. 


\section{E. Kesimpulan Dan Saran}

\section{Simpulan}

$$
\text { Pembelajaran dengan }
$$

metode quantum teaching dapat meningkatkan motivasi belajar siswa, khususnya pada pokok bahasan penampakan bulan. Hal ini dapat dilihat dari data sebelum siklus menunjukkan motivasi belajar siswa yang masih rendah, pada siklus I meningkat menjadi $45,5 \%$, dan pada siklus II meningkat menjadi $82 \%$.

\section{Saran}

Atas dasar simpulan tersebut disarankan:

1. Sebagai bahan pertimbangan hendaknya guru IPA kelas IV SD dapat melakukan pembelajaran IPA dengan menerapkan metode pembelajaran quantum teaching, sehingga pembelajaran menjadi lebih optimal.
2. Dari hasil penelitian ini juga memungkinkan diadakannya penelitian lebih lanjut sehingga diperoleh kemampuan yang lebih tinggi.

\section{Daftar Rujukan}

DePorter, B., Reardon, M., \& Nurin, S. (2010). Mempraktikkan Quantum Learning di ruang-ruang kelas. Bandung: PT. Mizan Pustaka

Sardiman. (2012). Interaksi dan Motivasi Belajar Mengajar. Jakarta: Raja Grafindo Persada

Tu'u, T. (2004). Peran disiplin pada perilaku dan prestasi siswa. Jakarta. PT Grasindo

Baharuddin. (2010). Pendidikan \& Psikologi Perkembangan. Jogjakarta: Ar-Ruzz Media

Arikunto, (2006). Penelitian Tindakan Kelas. Jakarta: PT. Bumi aksara 